\title{
Cointegration analysis for rice production in the states of Perlis and Johor, Malaysia
}

\begin{abstract}
Rice is ranked the third most important crop in Malaysia after rubber and palm oil in terms of production. Unlike the industrial crops, although its contribution to Malaysiaôs economy is minimal, it plays a pivotal role in the countryô food security as rice is consumed by almost everyone in Malaysia. Rice production is influenced by factors such as geographical location, temperature, rainfall, soil fertility, farming practices, etc. and hence the productivity of rice may differ in different state. In this study, our particular interest is to investigate the interrelationship between the rice production of Perlis and Johor. Data collected from Department of Agriculture, Government of Malaysia are tested for unit roots by Augmented Dickey-Fuller (ADF) unit root test while Engle-Granger (EG) procedure is used in the cointegration analysis. Our study shows that cointegrating relationship exists among the rice production in both states. The speed of adjustment coefficient of the error correction model (ECM) of Perlis is 0.611 indicating that approximately $61.1 \%$ of any deviation from the longrun path is corrected within a year by the production of rice in Johor.
\end{abstract}

Keyword: Rice production; Unit root; Long-run; Cointegration; Error correction; Speed of adjustment 